\title{
ТРЕТЕЙСЬКІ СУДИ ТА ДОСТУП ДО ПРАВОСУДДЯ
}

Козакевич О. М.

у статmі розглядається законодавча регламентація процедури врегулювання спору третейськими судами як альтернативного способу забезпечення доступу до правосуддя. Аналізуються теоретичні та практичні аспекті діяльності третейських судів. Про актуальність аналізованої проблеми свідчить неоднозначність і суперечливість наукових підходів до питань компетенції третейських судів у сучасній вітчизняній правовій доктрині. Проаналізовано існуючі в юридичній літературі різні точки зору щодо правової природи третейського розгляду спорів. Розкрито особливості третейського судочинства як позасудової форми захисту прав суб'єктів правових відносин. Доведено, що третейське судочинство як інститут громадянського суспільства має ефективно конкурувати з державою за здійснення правосуддя. Виходячи з принципів незалежності та альтернативності третейських судів, пріоритету захисту приватних інтересів сторін спору, розширення сфери застосування третейського розгляду правових спорів має великий потенціал. Розкрито переваги третейського судочинства над іншими способами захисту прав людини.

Зроблено висновок про те, що третейське судочинство не набуло широкого застосування у сфері вирішення правових спорів. Названо основні причини непопулярності третейського способу розгляду спорів в Україні серед фізичних осіб. На підставі аналізу законодавства про третейські суди та практики його застосування зроблено висновок про необхідність удосконалення процедури третейського судочинства. Шляхами вдосконалення є: належне інформування суб'єктів правовідносин про третейські суди як альтернативний спосіб вирішення спорів; формування високого рівня правосвідомості у населення; усунення законодавчих недоліків регулювання третейського розгляду з урахуванням сучасних тенденцій.

Ключові слова: альтернативне вирішення конфліктів, правовий конфлікт, права людини, право на справедливий суд, правова процедура, доступ до правосуддя, третейські суди, третейське судочинство, арбітраж, медичний арбітраж.

(c) Козакевич О. М., 2020
Kozakevych 0. M. Arbitral tribunals and access to justice

The article considers the legislative regulation of the dispute settlement procedure provided by arbitral tribunals an alternative mean that ensures access to justice. Theoretical and practical aspects of the arbitral tribunal activity are analysed. The relevance of the analysed problem is increasing in consideration of controversial and inconsistent methodological approaches to the competence of the arbitral tribunals in contemporary national legal doctrine. Various points of view on the legal nature of arbitration are analysed. The peculiarities of arbitration proceeding as extrajudicial protection of the subjects of law are revealed. It is proved that arbitration, as an institution of civil society, must compete effectively with the state for the administration of justice. Great potential of the arbitration is conditioned by the principles of independence and alternativeness of courts of arbitration, the priority of protection of the private interests of the parties to a dispute. The advantages of arbitration before other means of protection of subjective rights are revealed.

It is concluded that arbitration has not been widely used for legal disputes resolution. The main reasons for the unpopularity of the arbitration method of the dispute resolution in Ukraine are named. Based on the analysis of the legislation on arbitral tribunals and the practice of its application, a conclusion was made about the need to improve the procedure of arbitration. Ways to improve are the following: proper informing of the subjects of legal relations about the arbitral tribunals as an alternative way of resolving disputes; elimination of legislative shortcomings in the regulation of arbitration, taking into account current trends.

Key words: alternative conflict resolution, legal conflict, human rights, the right to a fair trial, legal procedure, access to justice, arbitral tribunal, arbitration, medical arbitration.

Постановка проблеми та їі актуальність. Право кожної особи на вільний доступ до правосуддя зафіксовано в різних міжнародних правових актах, які визначають універсальні стандарти такого права. Прийнята у травні 1981 р. Рекомендація R (81) 7 Комітету міністрів Ради Європи державам-членам стосовно шляхів полегшення доступу до правосуддя закріплює такі складники 
концепції доступу до правосуддя: інформування громадськості про місцезнаходження і компетенцію судів, а також про порядок звернення до суду або ж захисту своїх інтересів у судовому порядку; спрощення процесу та заохочення сторін до примирення або дружнього врегулювання спору; прискорення провадження; скорочення судових витрат; створення особливих процедур по позовних вимогах на незначні суми [19]. Повна формула принципу вільного доступу до правосуддя міститься в Європейській конвенції про захист прав людини й основоположних свобод. Тлумачення окремих елементів цього принципу, а також його окремих елементів здійснено в низці рішень Європейського суду з прав людини.

Право на доступ до правосуддя деталізується й у національному законодавстві, рівень його доступу має бути достатнім для забезпечення права особи на суд з огляду на принцип верховенства права. Тривалий час радянська та пострадянська юридична наука виходили з того, що забезпечення доступу до суду з боку держави має бути гарантоване виключно вирішенням питання про судові витрати та забезпечення юридичної допомоги. Сучасна правова наука до нових форм доступу до правосуддя поступово відносить: інститут третейського розгляду спорів, інститут відновного правосуддя, інститут медіації.

Розвиток альтернативних способів вирішення спорів передбачено Стратегією реформування судоустрою, судочинства та суміжних правових інститутів на 2015-2020рр., затвердженою Указом Президента України від 20.05.2015 № 276, одними із завдань якої $\epsilon$ підвищення ефективності правосуддя та оптимізація повноважень судів різних юрисдикцій, у тому числі й шляхом розширення переліку способів альтернативного (позасудового) врегулювання спорів, практичного впровадження інституту медіації та посередництва, розширення переліку категорій справ, які можуть вирішуватися третейськими суддями або розглядатися судами у спрощеному провадженні [15]. Водночас ані в українського законодавця, ані у суспільства немає розуміння ефективного механізму інкорпорації альтернативних способів вирішення спорів у правову систему держави. Україна знаходиться в ситуації, коли практика використання таких процедур йде попереду правового регулювання.

Терміни «арбітраж» та «третейський суд» у вітчизняному та іноземному законодавстві, а також у науці та правовій практиці використовуються як синоніми. «Арбітраж» використовується як у міжнародній публічній практиці, так і міжна- родній приватній сфері. До компетенції третейських судів належать, як правило, всі справи по спорах, що виникають із цивільних правовідносин [23, с. 3]. Найбільш розвинені третейські інституції діють у державах сталої демократії та високого рівня правової культури населення. Так, у країнах Європи та США, де мають місце сталі традиції торгового обігу, третейськими судами розглядаються до $80 \%$ усіх господарських спорів. Це приклад ефективної реалізації права на альтернативні способи захисту, які базуються на приватноправовій автономії особистості, на принципах самоорганізації соціальних спільнот протягом багатьох століть. Принцип приватноправової автономії суб'єкта передбачає надання широких прав вибору способів захисту своїх прав, що $\epsilon$ гарантією їх реалізації.

Аналіз останніх досліджень і публікацій. Різні аспекти третейського судочинства та проблема правової природи третейського суду розглядалися у наукових роботах І. Бута, А. Гаврилішина, В. Козирєва, С. Короєда, Ю. Котвяковського, О. Переверзєва, Ю. Притики, В. Самохвалова, А. Ткачука та інших науковців. Водночас слід зазначити, що у наукових дослідженнях недостатньо уваги приділено питанню розгляду особливостей третейського судочинства як альтернативної юрисдикційної форми захисту прав людини.

Метою статті $\epsilon$ дослідження законодавчої регламентації процедури врегулювання спору третейськими судами як альтернативного способу забезпечення доступу до правосуддя та аналіз практичної діяльності третейських судів.

Виклад основного матеріалу. Сутність принципу доступу до правосуддя полягає у відсутності надмірних, необґрунтованих правових і практичних перешкод для розгляду справи в суді. Уперше невід'ємне право особи на доступ до правосуддя сформульовано у рішенні по справі «Голдер (Golder) проти Сполученого Королівства» 1975 р. Також у рішенні Європейський суд з прав людини дійшов висновку, що принцип верховенства права $\epsilon$ невід'ємним від доступу до правосуддя [22]. Основні аспекти доступу до правосуддя та його раціонального обмеження, викладені у рішенні «Дєєвир (Deweer) проти Бельгії». Відмова особи від права на звернення до суду часто передбачена у внутрішньому законодавстві держави у вигляді: арбітражних застережень та контрактів в галузі цивільного права; inter alia штрафів, що сплачуються в погоджувальному порядку у сфері кримінального права. Відмова, яка має незаперечні переваги для відповідної особи, а також для 
відправлення правосуддя, не порушує Конвенції [3]. У справі «Суда (Suda) проти Чеської Республіки» сформульовано положення, що особи можуть відмовитися від права доступу до суду і скористатися послугами третейського суду за умови, що така відмова можлива та висловлюється вільно і чітко [4].

У юридичній літературі висловлюються різні точки зору щодо правової природи третейського розгляду спорів. Автори методичного посібника «Третейські суди в Україні», висвітлюючи історичні аспекти третейського судочинства, звертають увагу на три основні підходи до вирішення спорів та конфліктів: із позицій сили, із позицій права та з позицій інтересів. Суть підходу з позицій сили полягає у тому, що одна або декілька сторін пригнічується за рахунок переваги іншої (фізична сила, кількісна або технічна перевага, гроші або діловий статус, репутація тощо). Підхід до вирішення конфліктів із позицій права ґрунтується на застосуванні судом закону, правил, інструкцій, нормативів тощо. Третій підхід до вирішення конфліктів - із позицій інтересів. Із метою вирішення спору сторони намагаються визначити, що стало причиною виникнення спору, i за можливості задовольнити ті інтереси, які були порушені. Найбільш поширеними способами вирішення спорів із позицій інтересів $є$ переговори, посередництво (медіація), арбітраж [23, с. 15-16]. Однією з таких альтернатив $\epsilon$ діяльність третейських судів, які в Україні виникли в 2004 р.

І. Бут робить висновок, що в науковій літературі поняття «третейський суд» використовується у трьох усталених значеннях: як сам орган, що безпосередньо здійснює розгляд правового спору; як форма захисту цивільного права, що $є$ альтернативою зверненню до суду чи інших державних юрисдикційних органів, та сам механізм такого захисту; як суддя чи склад конкретного третейського суду, що обираються (призначаються) для вирішення спору [1, с. 18].

Проаналізувавши законодавство України, судову практику та позиції вчених, С. Рабенко пропонує визначення третейського судочинства як складного юридичного явища, альтернативну юрисдикційну позасудову форму захисту прав, що дістає свого вияву у спеціальній процедурі розгляду та вирішення спорів, яка слугує гарантією законності в кожному конкретному випадку, відповідно до якої здійснюють свою діяльність незалежні від влади та сторін спору уповноважені державою органи, а саме внутрішні третейські суди та міжнародний комерційний арбітраж, які створено відповідно до законодавства України,
3 метою захисту порушених, оспорюваних або невизнаних прав та законних інтересів суб'єктів господарювання, які витікають із цивільних та господарських правовідносин і не охоплюють охорону державних та суспільних інтересів [17, с. 364].

Зазначимо, що третейський розгляд - це посередництво, засноване на цивільно-правовому договорі про встановлення прав. Так, щоб передати спір на розгляд третейського суду, сторонам необхідно укласти третейську угоду. Третейська угода може бути укладена у вигляді третейського застереження в договорі (контракті) або у вигляді окремої письмової угоди [16]. Основна мета третейської угоди - це застосування третейського розгляду як альтернативного способу вирішення спорів.

I. Переверзєв конкретизує визначення третейського судочинства у сфері господарської діяльності як альтернативну юрисдикційну позасудову форму захисту прав суб'єктів господарювання та учасників господарських відносин, яка має власну процедуру розгляду та вирішення спору з пріоритетом захисту приватних інтересів сторін спору, а не публічних інтересів держави. Автор виокремлює проблемні питання реалізації такої альтернативної процедури:

діяльність третейських судів для вирішення конкретного спору (судів ad hoc), які можуть утворюватися відповідно до ч. 1 ст. 7 Закону України «Про третейські суди»;

оскарження рішення третейського суду у господарському суді (Розділ VII Господарського процесуального кодексу);

виключення з числа справ, підвідомчих третейському суду, досить великої кількості господарських спорів [6, с. 301-302].

Таким чином, третейський розгляд спорів - це особлива юрисдикційна форма, альтернативна державному правосуддю у сфері приватного права, в основу якої покладено принцип автономії волі сторін.

Основним законодавчим актом, що встановлює правове статус третейських судів, порядок їх організації та діяльності в нашій країні, $€$ Закон України «Про третейські суди». Закон узагальнив світовий досвід практики третейських судів, третейські традиції, притаманні українським землям, та теоретичні ідеї науковців. У Законі третейський суд визначається як недержавний незалежний орган, що утворюється за угодою або відповідним рішенням заінтересованих фізичних та/або юридичних осіб у порядку, встановленому цим Законом, для вирішення спорів, що виникають 
із цивільних та господарських правовідносин. Завданням третейського суду $\epsilon$ захист майнових і немайнових прав та охоронюваних законом інтересів фізичних чи юридичних осіб шляхом усебічного розгляду та вирішення спорів відповідно до закону [16]. Зауважимо, що природа третейського суду виражена в його альтернативності державної судової системі.

Правові засади діяльності третейського суду у сфері розгляду спорів також становлять Цивільний кодекс, Цивільний процесуальний кодекс (розділ «Провадження у справах про оскарження рішень третейських судів, оспорювання рішень міжнародних комерційних арбітражі»), Господарський процесуальний кодекс (розділ «Провадження у справах про оскарження рішень третейських судів та про видачу наказів на примусове виконання рішень третейських судів»), закони України «Про заставу», «Про зовнішньоекономічну діяльність», «Про міжнародний комерційний арбітраж» [2; 12-14; 24; 25]. У цілому у вітчизняному праві сформовані необхідні правові умови для використання інституту третейського розгляду як основного процесуального засобу врегулювання господарських спорів з ініціативи сторін спору. Прийняті законодавчі акти, якими регулюються відносини у сферах внутрішнього третейського розгляду і міжнародного комерційного арбітражу.

Практика діяльності третейських судів висвітлена в Постанові Пленуму Вищого господарського суду України від 26.12.2011 «Про деякі питання практики застосування Господарського процесуального кодексу України судами першої інстанції» [11], узагальненні судової практики Верховним Судом України від 11.02.2009 «Практика застосування судами Закону України «Про третейські суди» [8].

Відповідно до закону, в Україні передбачається можливість утворення та дії постійно діючих третейських судів та третейських судів для вирішення конкретного спору (суди ad hoc). Постійно діючі третейські суди та третейські суди для вирішення конкретного спору утворюються без статусу юридичної особи. Постійно діючий третейський суд при Торгово-промисловій палаті України утворено рішенням Президії Торгово-промислової палати України від 22 вересня 2004 р. № 52 (1) і зареєстровано Міністерством юстиції України 8 листопада 2004 р. [18]. Кожен постійно діючий третейський суд підлягає державній реєстрації із затвердженням переліку третейських суддів, Положення про постійно діючий третейський суд та Регламенту, що безпосередньо і передбачається ст. 9 Закону України «Про третейські суди» [16].

Приймаючи справу до розгляду, третейський суд має вирішити питання щодо наявності в нього компетенції для вирішення такого спору. Так, Ю. Притика виділяє три головних критерії підвідомчості справ третейському суду: 1) характер спірних правовідносин; 2) суб'єктний склад сторін спору; 3) наявність угоди між сторонами спору [9, с. 224]. При цьому науковець акцентує увагу на «приватноправовому» характері спірних правовідносин.

У постанові Верховного Суду України від 21.10.2015 сформульована правова позиція, згідно з якою за змістом статей 1, 2, 6 Закону України «Про третейські суди» підвідомчість справ, які можуть бути вирішені в межах третейського судочинства, обмежена сферою лише приватного права. До сфери компетенції третейських судів належить вирішення спорів, що виникають між приватними особами з питань, які не стосуються публічно значимих відносин, і спір, що має публічно-правове значення, не підлягає вирішенню третейським судом [7].

Відмінність третейського судочинства від системи державних судів полягає у тому, що для останніх питання підвідомчості і підсудності справ, порядку порушення і розгляду справ визначено в імперативній формі у чинному процесуальному законодавстві. Під час розгляду справ третейським судом сувора необхідність дотримуватися процедурних правил відсутня, що надає третейським суддям та сторонам широку можливість пошуку варіантів досягнення взаємовигідного рішення та можливість вирішувати спір оперативно. Узагалі оперативність $€$ чи не найбільшою перевагою третейського розгляду перед державним судовим захистом. Вона забезпечується: процедурою формування третейського суду; відносно короткими рядками розгляду спору; за можливості - уникненням необхідності дотримання обов'язкових правил та процедур, характерних для відправлення правосуддя у державних судах; меншою завантаженістю порівняно з державними судами; узгодженістю дій сторін і сприятливим режимом для підтримання та збереження ділових, партнерських відносин між сторонами тощо [23, с. 25].

Відповідно до статей 5 та 6 Закону «Про третейські суди», на його розгляд можуть передаватися будь-які спори, що виникають між юридичними та/або фізичними особами із цивільних i господарських правовідносин. Закон зазнав 
великої кількості змін, найбільш суттєвими $\epsilon$ зміни до ст. 6 Закону, якими обмежено підвідомчість справ третейським судам. Так, Закон передбачає і перелік справ, які не можуть бути предметом третейського розгляду, це справи у спорах: про визнання недійсними нормативноправових актів; що виникають під час укладення, зміни, розірвання та виконання господарських договорів, пов'язаних із задоволенням державних потреб; пов'язаних із державною таємницею; що виникають із сімейних правовідносин, окрім справ у спорах, що виникають зі шлюбних контрактів; про відновлення платоспроможності боржника чи визнання його банкрутом; щодо нерухомого майна, включаючи земельні ділянки; про встановлення фактів, що мають юридичне значення; що виникають із трудових відносин; що виникають із корпоративних відносин у спорах між господарським товариством та його учасником; щодо захисту прав споживачів, у тому числі споживачів послуг банку, та ін. [16].

Нормативне обмеження компетенції третейських судів поступово призвело до зниження кількості справ, що розглядаються. Як свідчать статистичні показники, суди України у 2007 р. розглянули понад 13 тис справ про видачу виконавчого документа на рішення третейського суду та за результатами їх розгляду видано 12 тис 669 виконавчих документів, а в 2018 р. видано лише 10 виконавчих листів на виконання рішення третейського суду. Із наведеного вбачається величезний потенціал третейського розгляду спорів, який сьогодні практично не використовується.

На основі аналізу динаміки реєстрації третейських судів за різних типів організацій та інформації про їхню діяльність із вирішення справ починаючи з 2004 р. автори констатують, що за всю історію існування третейських судів 50\% із них так i не розглянули жодної справи попри те, що термінологічно в законі всі третейські суди іменуються як «постійно діючі», що не відповідає дійсності, враховуючи низький рівень їх доступності для взаємодії, зокрема той факт, що частина з них не тільки не були помічені у розгляді справ, а й не знаходяться за місцем реєстрації і не отримують кореспонденцію [26, с. 14].

У сучасних умовах $\epsilon$ низка об'єктивних причин, що сприяють розвитку конфліктних ситуацій у сфері медицині, які можуть стати причиною звернення пацієнтів не тільки до вищих медичних установ, а й до суду. Створення спеціалізованого третейського суду з розгляду мало б сприяти ефективному розгляду медичних справ, які виникають із правовідносин у сфері охорони здоров'я, та примиренню сторін. Так, президент ГО «Фундація медичного права та біоетики України» I. Сенюта пише про те, що як у національній практиці, так і в практиці зарубіжних країн (зокрема, РФ, США, Мексики) створено та діють медичні арбітражі. Перший вітчизняний і єдиний постійно діючий третейський суд при Всеукраїнській громадській організації «Фундація медичного права та біоетики України» створено у липні 2009 р. Разом із тим дотепер суд не розглянув жодної справи. Дослідниця (голова третейського суду) зазначає, що це зумовлено такими чинниками: відсутністю правової обізнаності суб'єктів медичних правовідносин щодо можливості вирішення справи через третейський суд; низьким рівнем правової культури суб'єктів спірних правовідносин, що породжує єдиний можливий варіант вирішення спору для них - судовий; внесенням змін до Закону України «Про третейські суди» в аспекті обмеження підвідомчості третейським судам спорів, пов'язаних із захистом прав споживачів, у т. ч. медичних послуг [21, с. 44]. Отже, особливої актуальності набуває питання розширення меж підвідомчості деяких категорій спорів третейським судам.

Разом із тим слід зазначити, що й досі третейське судочинство розвивається дуже повільно, неоднозначно сприймається як юристами, так і громадянами та залишається недостатньо дослідженим. Так, командою громадської організації «Фундація DEJURE» в рамках Програми «Нове правосуддя» здійснено аналітичне дослідження діяльності третейських судів в Україні та перспектив їх розвитку. За даними дослідження, станом на 1 грудня 2018 р. в Україні було зареєстровано 515 третейських судів, з них 21 припинив діяльність. В Інтернеті представлено 57 організацій, при яких утворено третейські суди. I лише 33 третейські суди мають власні сайти або розділи на сайтах організацій, при яких утворені, де оприлюднено їхній регламент, список третейських суддів, розміри третейського збору. Із 515 зареєстрованих третейських судів здійснювали діяльність 248 третейських судів [26, с. 7-9].

Із метою посилення ефективності функціонування національної системи третейських судів та відновлення довіри до третейського розгляду у квітні 2020 р. Кабінетом Міністрів України до Верховної Ради України було внесено проєкт закону України «Про внесення змін до деяких законів України щодо вдосконалення порядку утворення та діяльності третейських судів із 
метою відновлення довіри до третейського розгляду» (реєстраційний № 3411) [10] (слід зауважити, що це не першій законопроект, внесений до парламенту, наприклад законопроєкт № 3045 від 10.02.2020). Мета законопроєкту - удосконалити порядок утворення та діяльності третейських судів шляхом посилення вимог до організацій, при яких можуть діяти постійно діючі третейські суди, та розширення повноважень органів третейського самоврядування з метою ефективного здійснення третейського розгляду відповідно до найкращих європейських практик. Серед головних ідей розширення юрисдикції третейських судів - надання права розглядати спори у справах щодо нерухомого майна, а також уточнення компетенції третейського суду в частині розгляду справ у спорах щодо захисту прав споживачів та модифікація процедури розгляду справ, якою мають оперувати такі суди. Урядовий законопроєкт покликаний скоротити кількість третейських судів шляхом їх перереєстрації за підвищеними вимогами.

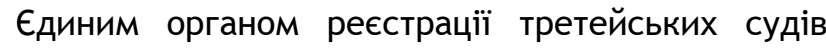
має стати Міністерство юстиції України, а давати висновок щодо відповідності третейського суду вимогам закону та критеріям, визначеним Bceукраїнським з"їздом третейських суддів, має Третейська палата України.

Із постійним зростанням кількості звернень суб'єктів права за захистом порушених прав підтверджується доцільність активного використання можливостей третейського судочинства. Переваги третейського розгляду полягають у тому, що воно звільняє перевантажену судову систему від великої кількості правових справ, дає можливість «здешевити» витрати на судовий розгляд спору й економічно для сторін спору. Великими плюсами $\epsilon$ : спрощеність процедури судового розгляду; стислі строки процесу розгляду справ; можливість вибору судді; можливість пред'явлення позову в третейський суд незалежно від місця знаходження відповідача; збереження конфіденційності, добровільність залученості до третейського процесу; свобода вибору правил третейського розгляду; контроль сторін за процедурою розгляду та їі результатом; остаточність рішення та можливість оскарження його лише за процесуальними підставами; негайне набрання чинності рішення третейського суду і можливість примусового його виконання.

Так, відповідно до Рішення Конституційного Суду України від 24 лютого 2004 р. (справа про виконання рішень третейських судів), рішення третейських судів водночас $\epsilon$ виконавчими доку- ментами, на підставі яких за заявою стягувача або його представника про примусове виконання рішення державні виконавці районних, міських (міст обласного значення), районних у містах відділів державної виконавчої служби мають забезпечити примусове виконання рішень цих судів, якщо інше не передбачено законом [20].

Щодо низької популярності третейського розгляду правових спорів у юридичній літературі називають такі причини: низький рівень правової культури та правової свідомості суспільства; нестабільна економічна ситуація в країні; необізнаність учасників цивільних правовідносин щодо діяльності третейських судів, їхнього місця в системі юрисдикційних органів; значний розмір третейського збору та інших витрат, пов'язаних із третейським розглядом, за відсутності пільг у їх сплаті; побоювання щодо упередженого розгляду справи третейським судом; занадто широкий перелік спорів, виключених із компетенції третейського суду; можливість оспорювання третейської угоди; відсутність ефективного механізму вжиття запобіжних заходів у третейському розгляді, у тому числі щодо забезпечення позову; необхідність подання заяви до компетентного суду з метою звернення рішення третейського суду до примусового виконання шляхом видачі виконавчого листа; можливість апеляційного та касаційного оскарження ухвал судів загальної юрисдикції щодо відмови у видачі виконавчого листа на примусове виконання третейського рішення, ухвал за результатами оскарження рішення третейського суду [1, с. 34].

Висновки. Таким чином, найбільш удалим прикладом реалізації альтернативних способів захисту, який базується на приватноправовій автономії особистості та принципах самоорганізації соціальних спільнот протягом багатьох сторіч, $\epsilon$ третейський розгляд. Із прийнятим Закону «Про третейські суди» Україна зробила крок до приєднання до держав із розвиненою системою альтернативних способів розв'язання правових конфліктів і продемонструвала всьому світу своє реальне прагнення до демократизації суспільства та здійснення правової реформи. Цей важливий елемент саморегулювання соціуму у різноманітних сферах життєдіяльності $\epsilon$ невід'ємним атрибутом ефективного функціонування механізму правопорядку, свідчить про високий рівень правосвідомості населення у правовій державі, про наявність злагоди у суспільстві і забезпеченість справедливості та демократії. 
Разом із тим в Україні хоча й існує велика кількість третейських судів, кількість розглянутих справ $\epsilon$ дуже низькою. Заходами для поліпшення ситуації $\epsilon:$ по-перше, забезпечення належного рівня інформування як пересічних громадян, так і професійних юристів про третейські суди як альтернативний спосіб вирішення спорів; по-друге, усунення законодавчих недоліків регулювання третейського розгляду з урахуванням сучасних тенденцій.

\section{Література}

1. Бут І.О. Розгляд цивільно-правових спорів третейськими судами в Україні : дис. ... канд. юрид. наук : 12.00.03. Одеса, 2016. 229 с.

2. Господарський процесуальний кодекс України : Закон України № 1798-XII від 6 листопада 1991 р. URL: https://zakon.rada.gov.ua/laws/ show/1798-12\#Text (дата звернення: 03.12.2020).

3. Дело «Девеер против Бельгии» : Решение Европейского Суда по правам человека от 27 февраля 1989 г. URL: https://precedent.in.ua/2016/04/08/ deveer-protyv-belgyy/ (дата звернення: 03.12.2020).

4. Дело «Суда (Suda) против Чешской Республики» : Решение Европейского Суда по правам человека от 28 октября 2010 г. URL: http://www.echr.ru/ documents/doc/2470905/2470905-001.htm (дата звернення: 03.12.2020).

5. Конвенція про захист прав людини і основоположних свобод від 11 листопада 1950 р. URL: http://zakon2.rada.gov.ua/laws/show/995_004. (дата звернення: 03.12.2020).

6. Переверзєв І.О. Третейське судочинство у сфері господарської діяльності: проблеми застосування та шляхи вирішення. Форум права. 2017. № 5. С. 298-304. URL: http://nbuv.gov.ua/j-pdf/FP_index.htm_2017_5_47. pdf (дата звернення: 03.12.2020).

7. Постанова Верховного Суду України від 21.10.2015, судова справа № 6-831цс15. URL: http: / / www. scourt.gov.ua/clients/vsu/vsu.nsf / (documents)/A05719BF4C8962A8C2257EF1004BF1A8 (дата звернення: 03.12.2020).

8. Практика застосування судами Закону України «Про третейські суди» : узагальнення судової практики Верховного Суду України від 11.02.2009. URL: http://zakon2.rada.gov.ua/laws/show/n_0057 00-09 (дата звернення: 03.12.2020).

9. Притика Ю.Д. Теоретичні проблеми захисту прав учасників цивільних правовідносин в третейському суді : дис. ... д-ра юрид. наук. Київ, 2006. $632 \mathrm{c}$.

10. Про внесення змін до деяких законів України щодо вдосконалення порядку утворення та діяльності третейських судів з метою відновлення довіри до третейського розгляду : проєкт закону України від 29.04.2020 № 3411. URL: https://w1.c1.rada.gov.ua/ pls/zweb2/webproc4_1?pf3511=68714.

11. Про деякі питання практики застосування Господарського процесуального кодексу України судами першої інстанції : Постанова Пленуму Вищого господарського суду України від 26.12.2011. URL: http: / /zakon2.rada.gov.ua/laws/show/v0018600-11 (дата звернення: 03.12.2020).

12. Про заставу : Закон України № 2654-XII від 2 жовтня 1992 p. URL: https: / /zakon.rada.gov.ua/laws/ show/2654-12\#Text (дата звернення: 03.12.2020).

13. Про зовнішньоекономічну діяльність : Закон України № 959-XII від 16 квітня 1991 р. URL: https:// zakon.rada.gov.ua/laws/show/959-12\#Text (дата звернення: 03.12.2020).

14. Про міжнародний комерційний арбітраж : Закон України № 4002-XII від 24.02.1994. URL: https://zakon.rada.gov.ua/laws/show/4002-12/ print1329923525725369\#Text (дата звернення: 03.12.2020).

15. Про Стратегію реформування судоустрою, судочинства та суміжних правових інститутів на 2015-2020 роки : Указ Президента України № 276/2015 від 20 травня 2015 р. URL: https: / / zakon2.rada.gov.ua/laws/show/276/2015 (дата звернення: 03.12.2020).

16. Про третейські суди : Закон України від 11 травня 2004 р. № 1701-IV. URL: https:// zakon.rada.gov.ua/laws/show/1701-15\#Text (дата звернення: 03.12.2020).

17. Рабенко С.Л. Третейське судочинство як альтернативна юрисдикційна форма захисту прав суб'єктів господарювання. Часопис Київського університету права. 2012. № 2. С. 362-366.

18. Регламент постійно діючого третейського суду при Торгово-промисловій палаті України : Рішення Президії Торгово-промислової палати України № 52(1) від 22. 09. 2004. URL: https:// zakon.rada.gov.ua/rada/show/va052571-04\#Text (дата звернення: 03.12.2020).

19. Рекомендація R (81) 7 Комітету міністрів державам-членам стосовно шляхів полегшення доступу до правосуддя від 15 травня 1981 р. URL: https:// zakon.rada.gov.ua/laws/show/994_133\#Text (дата звернення: 03.12.2020).

20. Рішення Конституційного Суду України у справі за конституційним зверненням спільного підприємства «Мукачівський плодоовочевий консервний завод» про офіційне тлумачення положення пункту 10 статті 3 Закону України «Про виконавче провадження» (справа про виконання рішень третейських судів) № 3-рп/2004 від 24 лютого 2004 р. 


\section{Проблеми становлення правової демократичної держави}

URL: https://zakon.rada.gov.ua/laws/show/v003p71004\#Text (дата звернення: 03.12.2020).

21. Сенюта І.Я. Медичний арбітраж (третейство) в Україні. Медичне право. 2018. № 2(22). С. 41-49.

22. Справа «Голдер (Golder) проти Сполученого Королівства» : Рішення Європейского Суду з прав людини від 21 лютого 1975 р. URL: https: //zakon.rada.gov.ua/ laws/show/980_086\#Text (дата звернення: 03.12.2020).

23. Третейські суди в Україні / Ю.А. Михальський та ін. ; за ред. В.П. Самохвалова, А.Ф. Ткачука. Київ : Леста, 2007. 184 с.

24. Цивільний кодекс України : Закон України № 435-IV від 16 січня 2003 р. URL: https:// zakon.rada.gov.ua/laws/show/435-15\#Text (дата звернення: 03.12.2020).
25. Цивільний процесуальний кодекс України : Закон України № 1618-IV від 18 березня 2004 p. URL: https://zakon.rada.gov.ua/laws/ show/1618-15\#Text (дата звернення: 03.12.2020).

26. Третейські суди в Україні: стан розвитку, статистика, практика та перспективи / Т.П. Шепель та ін. Київ, 2018. 52 с.

Козакевич О. М., аспірантка кафедри загальнотеоретичної юриспруденції Національного університету «Одеська юридична академія» ORCID: 0000-0002-5528-7008 